\title{
KONSEP PENDIDIKAN DALAM PERSPEKTIF MUHAMMAD NATSIR
}

\author{
Firdaus \\ Universitas Islam Riau, Pekanbaru, Indonesia \\ e-mail : firdausrida@edu.uir.ac.id
}

\begin{abstract}
This study aims to determine the concept of education and Muhammad Natsir. The method used in this research is a qualitative method with a library research approach. The results of this study explain that education is something that is very important in human life. The urgency of education makes education experts give a lot of ideas in order to improve the quality of education itself. One of the national figures who cares about the world of education is Muhammad Natsir. Muhammad Natsir contributed many thoughts in order to advance education in Indonesia. According to Natsir, education must be based on Tauhid. Eliminating monotheism in the world of education is a very big mistake and also a very big negligence. Muhammad Natsir also offers an integral direction of education. This means that in the world of education there is no longer any separation between religion and science. Islam has a concept of not separating religion and science. Separating religion and science means opening up opportunities to secularize science and also to secularize education. The integration of science will make the science in the garden bring people to know who the creator is.
\end{abstract}

Keywords: Educational Consep, Muhammad Natsir.

\begin{abstract}
ABSTRAK
Penelitian ini bertujuan untuk mengetahui konsep pendidikan Muhammad Natsir. Metode yang digunakan dalam penelitian ini adalah metode kualitatif dengan pendekatan Library research. Hasil penelitian ini menjelaskan bahwa pendidikan merupakan sesuatu yang sangat urgen dalam kehidupan manusia. Urgennya pendidikan tersebut menjadikan para pakar pendidikan banyak memberikan pemikiran-pemikirannya dalam rangka meningkatkan kualitas dari pendidikan itu sendiri. Salah satu tokoh bangsa yang peduli terhadap dunia pendidikan adalah Muhammad Natsir. Muhammad Natsir banyak memberikan sumbangan pemikiran dalam rangka memajukan pendidikan di Indonesia. Menurut Natsir pendidikan haruslah berlandaskan Tauhid. Menghilangkan ketauhidan dalam dunia pendidikan merupakan suatu kesalahan yang sangat besar dan juga merupakan kelalaian yang sangat besar pula. Muhammad Natsir juga menawarkan arah pendidikan yang menyeluruh (integral). Artinya dalam dunia pendidikan tidak lagi mengenal pemisahan antara agama dan sains. Islam memiliki suatu konsep untuk tidak memisahkan antara agama san juga sains. Memisahkan agama dan sains berarti membuka peluang untuk mensekularisasikan ilmu pengetahuan dan juga mensekularisasikan pendidikan. Integrasi ilmu akan menjadikan ilmu pengetahuan tersebun membawa manusia untuk lebih mengenal siapa penciptanya.
\end{abstract}

Kata Kunci: Konsep Pendidikan, Muhammad Natsir

\begin{tabular}{c|c|c|c|}
\hline FIRST RECEIVED: & REVISED: & ACCEPTED: & PUBLISHED: \\
29 June 2020 & 18 October 2020 & 31 October 2020 & 12 Desember 2020 \\
\hline
\end{tabular}




\section{PENDAHULUAN}

Pendidikan sesuatu yang sangat penting dalam kehidupan manusia. Salah satu indikator yang menunjukkan begitu pentingnya pendidikan tersebut adalah semakin sadarnya para orang tua untuk menyekolahkan anaknya sejak anaknya tersebut berusia dini. Pendidikan diharapkan dapat merubah kehidupan manusia. Terlebih dalam hal akhlaq dan kualitas manusia dihadapan Khaliq. Karena tujuan diciptakan seorang manusia untuk pengabdian kepada sang Khaliq.

Begitu pentingnya pendidikan dalam kehidupan manusia dalam rangka meningkatkan harkat dan martabat manusia itu sendiri maka pendidikan perlu menyiapkan manusia yang tidak hanya memiliki intelaktual yang tinggi namun juga harus memiliku spiritualitas dan al akhlaqul karimah (Hasan Baharun, 2016: 96).

Pendidikan tidak dapat dilepaskan dari akhlaq ataupun etika (Islam). Suatu kesalahan yang fatal jika manusia menghilangkan akhlaq dalam kehidupannya. Karena kemampuan dan keterampilan yang tinggi yang tidak dilandasi dengan akhlaq akan menelanjangi manusia dari sisi etika dan juga kesopanan. Jatuh bangunnya suatu bangsa akan tergantung pada bagaimana kualitas akhlaq yang ada pada bangsa tersebut (Imam Muslih, 2018: 187).

Dewasa ini faham sekularisai sudah masuk disegala sendi kehidupan manusia. termasuk dalam dunia pendidikan. Faham sekular ini menina bobokkan kita untuk selalu melegalkan faham dikotomi ilmu. Yaitu suatu anggapan bahwa ilmu tersebut terdiri dari ilmu agama dan ilmu sains. Demikian juga dalam dunia pendidikan. Mata-pelajaran sudah diklasifikasikan mana mata pelajaran agama dan mana mata pelajaran umum (sains). Adanya dikotomi ilmu juga membuat terbelahnya kelembagaan pendidikan. Faham tersebut memunculkan adanya sekolah Madrasah Ibtidaiyah dan sekolah Dasar, adanya MTs dan SMP, juga MA dan SMA. Jika orang tua ingin menjadikan anaknya memiliki ilmu agama maka orang tua tersebut akan menyekolahkan anak-anaknya kelembaga Islam seperti MTs, MA ataupun pondok. Sekolah umum -baca SMP, SMAdianggap tidak dapat mendidik seorang anak menjadi generasi yang memiliki pengetahuan agama yang mumpuni. Faham sekuler ini menghancurkan sendi-sendi keislaman. Faham ini akan menjadikan umat Islam hanya menggunakan ilmu dan akal saja dengan mengesampingkan hal-hal yang bersifat immaterial (M. Syukri Ismail, 2014:112).

Islam tidak mengenal adanya pemisahan ilmu. Ajaran Islam sempurna dan bersifat universal yang memiliki fungsi sebagai rahmat bagi seluruh alam (St. Noor Farida Laila, 2016:384). Ilmu yang dipelajari untuk mengenal Allah dan mengenal kekuasaan dan kebesaran Allah yang pada akhirnya membawa manusia kepada penghambaan yang total kepada Allah SWT.

Muhammad Natsir sebagai salah seorang yang peduli terhadap pendidikan menawarkan konsep dalam dunia pendidikan. Konsep yang ditawarkannya dalam rangka menghilangkan faham sekularisme dengan dikotomi ilmunya dan membawa kepada ilmu yang terintegrasi yang bermuara kepada mentauhidkan Allah SWT. 


\section{METODE PENELITIAN}

Tulisan ini menggunakan jenis penelitian library research atau sering disebut dengan penelitian kepustakaan. Dalam penelitian kepustakaan ini peneliti konsen dalam mentelaah buku-buku ataupun artikelartikel yang berkaitan dengan objek yang sedang diteliti.

Untuk mendapatkan data dalam penelitian ini peneliti menggunakan data-data primer yang berasal dari buku-buku yang ditulis langsung oleh M.Natsir. adapun data skunder, peneliti mengambil data dari bukubuku dan juga jurnal yang berkaitan dengan apa yang sedang penulis teliti. Sumbersumber primer penulis mengambil dari bukubuku Muhammad Natsir seperti Capita Selecta, I dan II.

Adapun sumber sekunder penulis mengambil dari jurnal-jurnal yang memperkuat teori-teori dari sumber primer seperti jurnal dengan judul Integrasi dan Islamisasi Ilmu dalam Perspektif Pendidikan Islam karya Fauzi Amin, jurnal dengan judul Integrasi Ilmu dalam Perspektif Al-Quran karya Muhammad Hanafi dan masih banyak lagi jurnal-jurnal lainnya. Setelah data didapat dari sumber-sumber primer ataupun sekunder. Maka peneliti menganalisa data tersebut melalui langkah-langkah; Pertama, Deskriptif, yaitu memaparkan data atau menggambarkan keterangan yang menjadi objek dari telaah. Kedua, analisis sintesis, yaitu menganalisa suatu tulisan untuk mendapatkan fakta atau jawaban yang tepat, mengenai asal usul dan penyebabnya dari yang bersifat umum kepada yang lebih khusus. Ketiga, Heuristik Yaitu melakukan penelaahan secara mendalam terhadap hal-hal yang berkaitan dengan prosedur analisis yang dimulai dengan perkiraan yang tepat dan mengeceknya kembali sebelum memberi kepastian, atau lebih tepatnya adalah tekhnik penelitian dengan maksud untuk menemukan ide yang baru.

\section{HASIL DAN PEMBAHASAN Biografi Muhammad Natsir.}

Muhammad Natsir adalah salah satu tokoh bangsa yang memberikan kontribusi yang sangat besar baik di dunia politik, agama dan juga pendidikan. Beliau merupakan figur yang memiliki kesederhanaan yang tinggi. Muhammad Natsir dilahirkan di Alahan Panjang, lembah Gumanti, Kabupaten Solok Sumatera Barat pada tanggal 17 Juli 1908.

Jenjang pendidikan yang dilaluinya adalah Sekolah Rakyat di Maninjau yang dilaluinya selama dua tahun. Selanjutnya ia juga pernah mengecap pendidikan di Hollandsch Inlandsche School (HIS) di Padang. Selain belajar di HIS, untuk menambah ilmu tentang agamanya Natsir juga menimba ilmu keagamaan di Madrasah Diniyah saat malam hari. Pada tahun 1923 Natsir meneruskan studinya di Meer Uitgebreid Lager Onderwijs (MULO). Setelah menyelesaikan pendidikannya di MULO beliau melanjutkan di Algemene Middelbare School (AMS) di Bandung.

Selain gemar dalam menuntut ilmu, Natsir juga tertarik dalam urusan organisasi. Pada tahun 1928 sampai 1932 Natsir menjadi ketua Jong Islaminten Bond (JIB) Bandung.

Pada tahun 1950 Muhammad Natsir diangkat sebagai Perana Menteri oleh Presiden Soekarno. Pada masa inilah Natsir banyak mengkritik Presiden Soekarno tentang pemerataan kesejahteraan yang pada waktu itu hanya terpusat di pulau Jawa saja dengan 
tidak memperhatikan kesejahteraan diluar Jawa. Kritikan-kritikan Natsir terhadap pemerintah menjadikan dirinya dicap sebagai pemberontak dan pembangkang sehingga tudingan tersebut menghantarkan beliau kepenjara.

Muhammad Natsir diakui dalam dunia Islam sebagai pahlawan lintas bangsa serta Negara. Hal ini disebabkan karena Muhammad Natsir merupakan salah satu politisi yang berada dalam barisan depan dalam membantu pembaharuan Islam. Natsir juga sempat mendapatkan penghargaan bintang Nichan Istikhar. Hal tersebut didapatinya atas perjuangannya dalam rangka mewujudkan kemerdekaan bangsa Afrika utara.

\section{Konsep Pendidikan dalam Pandangan Muhammad Natsir}

Pemikiran Muhammada Nasir banyak berkenaan dengan pemikiran politik Islam. Akan tetapi Muhammad Nasir dalam kiprahnya sebagai seorang pemikir juga banyak memberikan ide-ide dan pemikiran dalam bidang pendidikan. Sebagai seorang muslim yang taat, Muhammad Natsir memiliki pandangan bahwa Islam adalah agama Tauhid yang mana salah satu tujuan dari tauhid tersebut adalah menjauhkan manusia dari segala macam bentuk penghambaan kepada selain Allah. Sehingga jiwa manusia tersebut merdeka dari segala macam tuntutan-tuntutan yang berasal dari selain Allah. Selain itu Tauhid merupakan sebuah landasan yang paling utama dan identitas bagi seorang muslim (Usup Romli, 2012:2). Natsir berpendapat bahwa mentauhidkan Allah merupakan modal dasar bagi pendidikan. Yang mana mengajarkan
Tauhid dalam pendidikan merupakan bentuk cinta seorang pendidik terhadap anak didiknya (Natsir, 2008:159).

Apabila dikaitkan dengan pendidikan, pemikiran Muhammad Natsir ini bertujuan untuk menanamkan ketauhidan pada peserta didik. Yang mana penanaman ketauhidan adalah menjadi tugas dari para Rasul dan juga Nabi-nabi Allah swt. Tidak berlebihan jika konsep ketauhidan ini diletakkan oleh Muhammad Nastir pada konsep pendidikannnya. Apabila dikaji apa yang dilakukan oleh Rasulullah saw ketika pertama kali berdakwah, Rasul tidak mendakwahkan perintah sholat, puasa dan ibadah-ibadah lainnya. Akan tetapi Rasulullah pertamakali mendakwahkan permasalahan Tauhid. Ajaran Tauhid menduduki tingkatan yang tinggi karena Tauhid mengarahkan manusia pada kehidupan yang pasti yang dengan tauhid itu pulalah manusia dapat membangun hubungan yang baik antara manusia itu sendiri dengan Rabb Nya.

Masih menurut Natsir Menghilangkan Tauhid dalam masalah pendidikan merupakan kesalahan yang tidak dapat ditolerir. Meninggalkan tauhid merupakan salah satu pengkhianatan terhadap amanah Allah dan juga merupakan penghianatan terhadap peserta didik walaupun kita telah memberikan dan memenuhi kebutuhannya (Natsir, 2008:160). Begitu pentingnya Tauhid dalam dunia pendidikan bagi Natsir sehingga ajaran Tauhid tidak bisa ditebus dengan pelajaranpelajaran lain. Tauhid akan membebaskan manusia dari penyembahan kepada makhluk menjadi penyembahan hanya kepada Khaliq (Roni Ismail, 2014:181). Hilangnya tauhid dalam dunia pendidikan sama dengan 
penjerumusan peserta didik kepada sesuatu yang sangat menakutkan.

Apabila dikaitkan dengan tujuan pendidikan Nasional, tujuan pendidikan nasional adalah mengembangkan potensi peserta didik agar menjadi manusia yang beriman dan bertakwa kepada Tuhan Yang Maha Esa, berakhlak mulia, sehat, berilmu, cakap, kreatif, mandiri, dan menjadi warga negara yang demokratis serta bertanggung jawab (UU No. 20 tahun 2003).

Dari tujuan pendidikan yang telah ditetapkan oleh pemerintah sepintas ada kesamaan dengan pemikiran Muhammad Natsir. Pendidikan Nasional memiliki tujuan untuk Bertaqwa kepada Tuhan Yang Maha Esa . Sedangkan pemikiran pendidikan Muhammad Natsir mewajibkan ajaran Tauhid dalam dunia pendidikan. Untuk menanamkan ketauhidan dalam dunia pendidikan Muhammad Natsir memberikan konsep pendidikan yang universal, integral. Muhammad Natsir sangat tidak menyukai pendidikan yang bersifat parsial, menurut beliau pendidikan haruslah universal, artinya pendidikan tersebut memiliki suatu keseimbangan antara akal, agama, fisik dan ruhiyah, dan kesemuanya itu terintegrasi dan tidak ada pemisahan antara ilmu tersebut .

Pendidikan yang holistik haruslah berlandaskan ketauhidan yang tujuan akhirnya adalah penghambaan manusia kepada Allah SWT dan terwujudnya kesempurnaan hidup didunia ataupun akhirat. Pendidikan juga haruslah berkisar antara dua dimensi yaitu dimensi ilahiyah dan dimensi insaniyah (Nurhadi dan Zainul, 2019:146). Maka Tauhid harus dijadikan landasan dalam menyelaraskan antara dimensi Ilahiyah dan dimensi insaniyah tersebut. Menurut
Natsir, Jika pendidik dalam hal ini guru dan para orang tua betul-betul cinta kepada anak didiknya maka pendidik haruslah mendidik dengan landasan Tauhid, karena hal tersebut merupakan bentuk cinta pendidik terhadap anak-anaknya (Natsir, 2008:142).

Merurut Natsir, Tauhid hendaklah ditanamkan ketika peserta didik masih belia. Penanaman nilai-nilai ketauhidan yang dimulai sejak dini akan menjadikan anak tersebut mudah untuk dituntun kepada hal-hal kebaikan. Penanaman ketauhidan ini hendaknya dilakukan sebelum peserta didik tersebut diberikan bekal berupa ilmu-ilmu yang lainnya. Hal tersebut bertujuan agar mereka benar-benar mengenal penciptanya dan hanya bergantung kepada satu pencipta. Hal tersebut sangat perlu untuk diperhatikan karena memupuk hubungan kepada pencipta harus lebih diutamakan dari pada memupuk hubungan terhadap sesama manusia. Karena menjalin hubungan kepada Allah tidak dapat ditunda-tunda sampai peserta didik tersebut besar ataupun dewasa (Natsir, 2008:143).

Dari pemikiran-pemikiran Mohammad Natsir diatas dapat kita simpulkan bahwa Natsir benar-benar memperhatikan masalah ketauhidan, sehingga menjadikan Tauhid tersebut sebagai landasan dan dasar dari pendidikan. Pendapat Muhammad Natsir ini dilatar belakangi oleh aqidahnya yang kuat dan dibarengi dengan ghiroh ataupun keinginan untuk menegakkan kalimat Allah SWT. Selanjutnya akan timbul dalam pemikiran, mengapa pendidikan harus berlandaskan Tauhid? Pendidikan yang akan menghasilkan ilmu jika tidak dilandasi dengan ketauhidan akan mengakibatkan peserta didik kita akan kehilangan tempat bergantung. Selain itu, manusia yang terdiri 
dari unsur ruhiyah pasti membutuhkan hal-hal yang ghaib sebagai penolongnya dan sebagai sesembahannya. Apabila hal tersebut tidak didapatinya maka akan menjadi suatu permasalahan yang sangat beasar dalam kehidupannya (Natsir, 2008:158).

Jadi Tauhid yang dijadikan landasan oleh Natsir sebagai landasan pendidikan tidak hanya sebagai landasan pembentukan keimanan dan ketaqwaan. Lebih dari itu Tauhid ini dijadikan sebagai pemenuhan dari tuntutan ruhani yang ada pada diri manusia itu sendiri. Karena salah satu sifat ruhani manusia tersebut adalah butuhnya kepada kekuatan ghaib yang dengan kekuatan tersebut manusia akan merasa nyaman dengannya. Ketika ruhani membutuhkan tempat berlindung dan bergantung, maka hal tersebut tidak akan didapati kecuali kembali kepada kebesaran Allah SWT. Ketenangan ruhiyah tersebut tidak akan didapati dengan pesatnya perkembangan ilmu pengetahuan. Akan tetapi ketenangan tersebut akan didapai dengan kembali kepada Allah melalui jalan mentauhidkannya.

Dari sini dapat dilihat bahwa Natsir tidak menginginkan pendidikan yang bersentralkan hanya kepada ilmu pengetahuan semata. Akan tetapi pendidikan juga harus memperhatikan masalah ruhani peserta didik. Yang mana permasalahan ruhani tersebut haruslah didahului dengan penanaman dan pemantapan Tauhid. Pemikiran Natsir tentang tujuan pendidikan ini didasari dari keyakinan Natsir dalam mengamalkan firman Allah QS $\mathrm{Adz}$ Dzariat ayat 56 yang artinya :"Dan tidaklah aku jadikan golongan Jin dan Manusia melainkan untuk menyembahku".

Menurut Natsir penyembahan kepada Allah adalah bentuk pengabdian yang tertinggi serta bentuk ketaatan dan ketundukan terhadap apa yang diinginkan oleh Allah. Dan apa yang dilakukan tersebut akan membawa kepada kebahagiaan baik didunia maupun diakhirat serta menjaukan dari apa-apa yang menghalangi untuk mendapatkan kebahagiaan yang abadi tersebut (Natsir, 2008:86).

Pendidikan yang integral yang harus diusahakan oleh manusia harus lah memiliki ciri yang khusus yaitu berlandaskan ketauhidan. Pendidikan yang integral ini akan menghilangkan dikotomi ilmu dan fahamfaham secular yang masuk melalui dunia pendidikan. Yang mana faham sekular ini hanya mengakui hal-hal yang bersifat kebendaan dan menafikan hal-hal yang berbau metafisik (Amin Fauzi, 2017: 3). Selain itu dikotomi ilmu juga membuat adanya jurang pemisah antara "ilmu agama" dan "ilmu sain". Bahkan kadang terkesan adanya pengingkaran terhadap ilmu-ilmu agama dan juga perlakuan rendah terhadap ilmu agama itu sendiri (Muchlis M Hanafi, 2010:176).

Untuk itulah pendidikan yang integral selain membawa manusia pada satu penghambaan kepada Allah, pendidikan yang integral juga harus dapat memerangi fahamfaham sekular yang dapat mengahancurkan sendi-sendi agama dan juga menghilangkan marwah dari agama itu sendiri. Integral apabila dilihat dalam kamus besar bahasa Indonesia berarti mengenai keseluruhan; meliputi seluruh bagian yang perlu untuk menjadikan lengkap; utuh bulat; tidak terpisahkan; terpadu. Maka pendidikan yang integral menurut Muhammad Natsir adalah pendidikan yang tidak dipisahkan, lengkap dan menyeluruh. Artinya pendidikan tersebut 
tidak hanya berorientasi kepada dunia semata atau hanya berorientasi kepada akhirat semata akan tetapi pendidikan tersebut sesuatu yang utuh yang berorientasi kepada dunia ataupun akhirat.

Pemikiran Muhammad Natsir tentang pendidikan ini adalah hasil pemikiran beliau melalui perenungan-perenungan yang didasari oleh al-Quran dan sunnah. Timbulnya pemikiran Natsir ini juga dilatar belakangi oleh reaksi dari mengapa pendidikan yang integral ini tidak dapat ditemui pada masa sekarang ini. Padahal ulama-ulama terdahulu sudah melaksanakannya. Dampak nyata dari adanya dikotomi ilmu tersebut umat Islam tertinggal dalam segala hal terutama dalam bidang sains. Umat Islam terlena ritual-ritual peribadatan dan meninggalkan ilmu pengetahuan (sains) yang berimplikasi pada pendidikan yang parsial.

Hal diatas memberikan dampak terhadap sangat minimnya sumbangan umat Islam dibidang sains. Sementara itu sains sangat pesat perkembangannya yang mana sumbangan tersebut berasal dari yang berlabelkan bukan Islam. (Abu Darda,2015:39). Selain hilangnya konsep integral dalam pendidikan disebabkan oleh kerancuan berfikir dalam mencari sumber ilmu pengetahuan. Artinya banyak dikalangan orang muslim tidak mau menerima ilmu pengetahuan dari Barat dan hanya mau menerima ilmu pengetahuan dari timur. Menurut Nastir inilah salah penyebab tidak terjadinya pendidikan yang integral. Menurut Natsir seorang pendidik Islam tidak harus mempertentangkan antara keilmuan yang datangnya dari Barat maupun keilmuan yang datangnya dari timur. Akan tetapi selama hal tersebut benar maka patutlah diambil dan dicontoh tanpa mempersoalkan apakah kebenaran tersebut datangnya dari dari Barat maupun Timur. Dalam Islam hanya mengenal dua kata yaitu antara haq dan bathil, sesuatu yang haq walaupu datangnya dari manapun maka kita harus menerimanya. Demikian juga dengan kebatilan. Walaupun datangnya darimanapun maka kebatilan tersebut harus dibuang dan disingkirkan.

Dari pemikiran Natsir ini dapat dilihat bahwasannya Natsir dalam mencari ilmu pengetahuan tidaklah berkiblat pada kelompok barat ataupun kelompok timur. Hal ini menunjukkan suatu keobjektifan beliau dalam berfikir dan menerima kebenaran. Muhammad Natsir tidak mengkultuskan bahwa kebenaran tersebut haruslah datang dari Timur. Demikian juga beliau tidak memfonis bahwa apa yang datang dari barat tersebut adalah sesat. Pemikiran Natsir ini apabila ditinjau dari sudut pandang filsafat maka pemikiran ini termasuk dalam aliran progesivism. Artinya Natsir memiliki pandangan kedepan untuk kemajuan ilmu pengetahuan Natsir memandang kedepan untuk kemajuan keilmuan ataupun pendidikan. Artinya Natsir secara tidak langsung telah mempersiapkan generasi muda untuk bersaing dalam menghadapi era globalisasi.

Inilah salah satu konsep yang integral dari Muhammad Natsir berupaya untuk menggabungkan ilmu-ilmu umum yang diwakili dari dunia bagian Barat dan ilmuilmu agama yang diwakili dari dunia bagian Timur. Dari sini nampak bahwa Natsir berupaya menggabungkan kedunya dalam rangka mentauhidkan Allah swt. dunia barat dengan kemajuan tekhnologinya dan dunia Timur dengan ilmu-ilmu Naqliyahnya. 
Bagaimana dua ilmu tersebut disinergikan sehinggga menuntut ilmu tersebut betul-betul untuk mewujudkan ketauhidan kepada Allah Swt. Menurut Natsir tujuan pendidikan menurut konsep Barat yang hanya mengejar dunia tidaklah dapat kita hilangkan sama sekali. Karena sudah menjadi suatu fitroh bagi manusia yang menginginkan dunia. Sebab sebagai hamba Allah SWT juga membutuhkan dunia yang dijadikan sebagai wasilah dalam rangka mendapatkan keridloaan dari Allah SWT.

Masih menurut Natsir, sistem pendidikan Timur yang lebih menonjolkan masalah kesucian batin juga tidaklah dapat kita akomodir secara keseluruhan. Hal ini disebabkan karena manusia memiliki dua unsur jasmani dan juga ruhani. Dan manusia dalam kehidupannya juga memiliki dua tujuan yaitu dunia dan akhirat yang kedua-duanya tersebut saling melengkapi dalam kerangka ketaatan dan kepatuhan kepada Allah.

Dari pemikiran Muhammada Natsir dapat dilihat bahwa Natsir menginginkan adanya keseimbangan antara tujuan dunia dan akhirat dalam suatu sistem pendidikan. Dengan keseimbangan tersebut maka akan terjadi keharmonisasian ilmu dalam pendidikan. Dalam sautu tulisannya beliau berpendapat bahwa dalam kehidupannya sebagai manusia, manusia harus dapat menyeimbangkan antara kehidupan dunia dan akhirat, keseimbangan antara badan dan ruh, dan juga harus menjaga keseimbangan antara diri sendiri dan masyarakat sekitar (Natsir, 2008:86).

Pendidikan Islam akan dapat mengangkat harkat dan martabat manusia. Selain itu pendidikan Islam akan dapat membentuk akhlaq sekaligus menjadikan peserta didiknya dapat bersaing dalam menggapai kehidupan dunia ini. Selain itu pendidikan Islam juga dapat membentuk sumber daya manusia yang unggul dan menguasai berbagai disiplin ilmu pengetahuan. Yang pada akhirnya pendidikan Islam itu akan membawa peserta didiknya yang mampu menggenggam dunia dan mendapatkan kebahagiaan akhirat. Menurut Natsir untuk mewujudkan manusia yang berkualitas, maka pendidikan tersebut haruslah dapat mengerti apa yang dibutuhkan oleh manusia tersebut. Pendidikan juga harus dapat menjadi solusi dari persoalan-persoalan yang dihadapi manusia pada saat ini dan juga persoalan-persoalan yang dihadapi manusia pada masa yang akan datang. Untuk menjawab permasalahan diatas maka pendidikan harus dapat menyiapkan sumber daya manusia dari segala bidang. Baik di bidang ekonomi, sains, pertanian, kesehatan dan lain sebagainya.

Pemikiran Natsir ini sesuai dengan K13 yang berlangsung di Indonesia saat ini. Artinya pendidikan tersebut haruslah dapat memenuhi kebutuhan manusia dan tantangan zaman pada . Dalam era globalisasi saat ini semua kebudayaan dan semua pengetahuan masuk kenegara kita. Dengan masuknya semua kebudayaan dan ilmu pengetahuan dalam suatu Negara, maka sangat perlu untuk membekali generasi muda agar generasi muda tersebut terhindar dari faham bebeas nilai. Untuk itulah Natsir mencanangkan pendidikan yang integral dan pendidikan yang harmonis. Konsep pendidikan yang integral dan harmonis ini dijadikan sebagai alat ataupun kontrol bagi perkembangan ilmu pengetahuan. Jika ilmu tersebut berjalan sendiri-sendiri sesuai dengan disiplin ilmu 
tersebut. maka dikhawatirkan akan terjadi penyimpangan-penyimpangan. Atau dapat di katakan kemajuan keilmuan tersebut dapat menyimpang dari segi aksiologinya. Karena kemajuan ilmu tanpa adanya kontrol sangat membahayakan bagi kehidupan manusia itu sendiri. Dengan adanya pendidikan yang integral maka diharapkan adanya harmonisasi antara agama dan sains disatu sisi. Disisi lain diharapkan agama tersebut dapat dijadikan cikal bakal dalam kemajuan tekhnologi ataupun sains.

Dengan adanya integrasi ilmu dan harmonisasi ilmu maka tidak akan ada lagi pertikaian antara agama dan sains. Sains tidak merasa lebih tinggi dari agama, dan agama tidak lagi merasa tidak memerlukan sains. Inilah bentuk dari harmonisasi ilmu hasil dari pendidikan yang terintegrasi. Konsep pendidikan yang integral ini juga bisa berimplikasi pada integrasi dibidang sumber ilmu. Artinya pembahasan tentang ilmu tidak hanya semata-mata pada objek ilmu yang kasat mata saja, akan tetapi ilmu yang tidak kasat mata juga dijadikan objek dalam penggalian ilmu pengetahuan. Untuk dapat menguak hal-hal yang tidak kasat mata tersebut maka kita juga harus memberikan porsi yang lebih pada akal, hati dan wahyu (Mulyadi, 2005:38).

Seperti yang telah disinggung sebelumnya bahwa Natsir juga memberikan keseimbangan antara jasad dan ruh, keseimbangan antara dunia dan akhirat dan keseimbangan antara diri sendiri dan masyarakat. Yang untuk dapat mencapai keseimbangan tersebut juga dibutuhkan keseimbangan antara badan, akal dan hati.

Maka jika kita lihat apa yang disampaikan oleh Natsir diatas pendidikan tidak hanya sebatas mengelola akal manusia semata lebih dari itu pendidikan mengelalola segala yang ada pada manusia. Pendidikan harus dapat mengelola akal manusia yang mana dengan akal tersebut manusia dapat berfikir lebih baik dan menghadapi tantangan dan perubahan zaman yang akan dihadapinya. Aspek badan ataupun jismiyah yang ada pada manusia juga merupakan sesuatu yang sangat penting untuk dikelola dan dilatih. Karena badan akan menunjang aktifitas akal dalam berfikir. Kesempurnaan akal juga akan dipengaruhi oleh kesempurnaan dari jasmani. Qalbu adalah sesuatu yang utama dalam diri manusia. Karena barometer sehatnya akal dan badan adalah ada pada qalbu.Dikarenakan begitu pentingnya hati bagi manusia maka pendidikan hendaknya tidak hanya mengelola akal dan badan saja. Akan tetapi lebih dari itu pendidikan harus dapat mengelola hati (qalbu) yang ada pada peserta didik.

Muhammad Natsir, dalam pandangannya bahwa pendidikan yang integral tidak mengenal pemisahan antara ilmu agama, ilmu sains ataupun ilmu humaniora. Dalam Islam dikenal dengan sunnatullah yang untuk mengetahui sunnatullah ini diperlukan ilmu-ilmu sains dalam rangka menguak misteri-misteri alam yang terjadi. Selian itu dalam Islam juga dikenal dengan Syariat-syariat Allah yang hal tersebut dapat digali dan difahami melaui ilmu agama. Dan yang terakhir adalah ilmuilmu sosial humaniora dalam rangka mewujudkan kemaslahatan bagi manusia dimuka bumi ini. Dengan demikian menurut Muhammad Natsir semua ilmu tersebut bersumber dari Allah dan dibutuhkan oleh semua manusia dan digunakan dalam rangka peribadatan kepada Allah SWT. Karena 
semua ilmu tersebut bersumber dari Allah SWT, maka tidak ada pertentangan antara ilmu-ilmu tersebut bahkan Islam dan ilmu pengetahuan tersebut memiliki keselarasan sehinga memiliki satu titik temu (Eva Iryani, 2017:68). Dan jika kita temui suatu pertentangan maka hakikatnya adalah penyelidikan ilmiah yang dilakukan belumlah sampai pada kebenaran ilmiyah yang objektif.

Ilmu pengetahuan dan agama tidak ada pertentangan antara satu dan yang lainnya, maka ilmu-ilmu tersebut tidak menjadi persoalan yang besar jika diajarkan dilembaga-lembaga pendidikan Islam. Hal itu disebabkan oleh kemajuan tekhnologi dan perjalanan agama seseorang seharusnya tidak saling bertabrakan satu sama lainnya.(Ali Masrur, 2016:36). Mengenai urgensi pendidikan ini Natsir juga mengatakan bahwa keberadaan suatu kaum akan ditentukan oleh kualitas pendidikan pada Negara tersebut. Bangsa-bangsa yang pada awal mulanya mengalami kemerosotan dalam segala bidang, akan menjadi bangsa yang yang terpandang setelah bangsa tersebut mengadakan perbaikan dalam bidang pendidikan (Natsir, 2008:77).

Apa yang disampaikan oleh Natsir harusnya menjadi pemikiran bagi pemerintah kita pada saat ini. Negara kita tidak akan dapat bersaing dengan Negara lain jika Negara ini tidak memeperhatikan dengan serius masalah-masalah yang berkaitan dengan pendidikan. Jadi menurut Natsir, kemajuan suatu Negara tidak terlepas dari berkualitasnya pendidikan dinegara tersebut. Masalah pendidikan adalah permasalah bangsa yang sangat urgen melebihi masalahmasalah yang lainnya.

\section{SIMPULAN}

Dalam pemikirannya Muhammad Natsir menawarkan konsep pendidikan yang integral. Artinya pendidikan tersebut jauh dari dikotomi seperti apa yang digaungkan oleh pendidikan Barat yang sekuler. Pendidikan yang integral tidak mengenal pemisahan antara sains dan agama. Karena hakikat ilmu adalah untuk mengenal dan membesarkan Allah SWT. Menurut Natsir, memisahkan agama dan sains akan membuka peluang untuk mensekularisasikan ilmu pengetahuan dan juga pendidikan. Integrasi ilmu dalam sebuah pembelajaran akan menjadikan manusia lebih mengenal siapa penciptaya. Selanjutnya Natsir juga melandasi pendidikan tersebut dengan Tauhid. Artinya pendidikan yang diusahakan pada saat sekarang ini haruslah dapat membawa peserta didiknya kepada penghambaan yang murni kepada Allah SWT. Menghilangkan Tauhid dari pendidikan merupakan suatu kesalahan terbesar. Karena Tauhid merupakan landasan bagi setiap aktivitas yang dilakukan oleh seorang mukmin.

\section{DAFTAR PUSTAKA}

Darda, Abu. (2015). Integrasi ilmu dan Agama: Perkembangan Konseptual di Indonesia., J urnal at Ta'dib 10 (1), 33-46

Maimun Syamsudin, Ach. (2012) Integrasi Multidimensi Agama dan Sains. Yogyakarta: IRCiSoD

Masrur, Ali. (2016). Relasi Iman dan Ilmu Pengetahuan dalam Perspektif alQuran (sebuah Kajian Tafsir Maudhu'i), al Bayan Jurnal Studi alQuran dan Tafsir, 1 (1), 36

Fauzi, Amin. (2017). Integrasi dan Islamisasi Ilmu dalam Perspektif Pendidikan Islam. Jurnal Pendidikan Islam, 8 (1), 3 
Iryani, E. (2017). al-Qur'an dan Ilmu Pengetahuan. Jurnal Ilmiah Universitas Batanghari Jambi, 17(3), 66-83.

Muslih, I. (2018, September). Membangun Akhlaq Santri Melalui Kajian Kitab Ta'limul Muta'allim. In Prosiding Seminar Nasional Islam Moderat (Vol. 1, pp. 187-195).

Ihsan, Hamdani, dan Ihsan, Fuad. (2007). Filsafat Pendidikan Islam, Bandung:Pustaka Setia.

Baharun, H. (2016). Pendidikan Anak Dalam Keluarga; Telaah Epistemologis. PEDAGOGIK: Jurnal Pendidikan, $3(2)$.

Natsir, M. (2008). Capita Selekta I, Jakarta: Yayasan Bulan Bintang Abadi.

Natsir, M. (2008). Capita Selecta II, Jakarta: Yayasan Bulan Bintang Abadi.

Ismail, M. S. (2007). Kritik Terhadap Sekularisme (Pandangan Yusuf Qardhawi). Kontekstualita: Jurnal Penelitian Sosial Keagamaan, 29(1), 37177.

Kartanegara, Mulyadhi. (2005). Integrasi Ilmu: Sebuah Rekonstruksi Holistik, Jakarta: UIN Jakarta Press

Hanafi, M. M. (2010). Integrasi Ilmu dalam Perspektif Al-Quran. SUHUF Jurnal Pengkajian Al-Qur'an dan Budaya, 3(2), 175-191.

Nurhadi, N., \& Lubis, Z. B. (2019). The Concept Of Tauhid Education Value (Aqidah) In National Education System Perspective.. AL-ISHLAH: Jurnal Pendidikan, 11(2), 141-158.

Ismail, R. (2016). Hakikat Monoteisme Islam (Kajian atas Konsep Tauhid 'La Ilaha Illallah'). Religi: Jurnal Studi Agamaagama, 10(2), 172-183.

Laila, F. (2016). Dikotomi Keilmuan Dalam Islam Abad Pertengahan (Telaah Pemikiran Al-ghazali Dan Al-zarnuji). IAIN Tulungagung Research Collections, 16(2), 383-399.

Sungkowo,S.(2014) Konsep Pendidikan Akhlak (Komparasi Pemikiran Al- ghazali dan Barat). Nur El-Islam, 1(1), 33-62.

Romli, U. (2012). Model Pendidikan Tauhid pada Keluarga Pengusaha Religius. Jurnal Tarbawi Vol, 1(1).1-10 